\title{
Seroprevalence and Spatial Distribution of Hepatitis C Virus in Bahia, Brazil
}

\author{
Felicidade Mota Pereira, ${ }^{1,2}$ Fred Luciano Neves Santos, ${ }^{1}$ Maria da Conceição Chagas de Almeida, ${ }^{3}$ Roberto Perez Carreiro, ${ }^{4}$ \\ Luciano Kalabric Silva, ${ }^{5}$ Bernardo Galvão-Castro, ${ }^{1,5}$ and Maria Fernanda Rios Grassi ${ }^{1,5 *}$ \\ ${ }^{1}$ Advanced Public Health Laboratory, Gonçalo Moniz Institute, Fiocruz-BA, Salvador, Bahia, Brazil; ' ${ }^{2}$ Gonçalo Moniz Public Health Central Laboratory, \\ Salvador, Bahia, Brazil; ${ }^{3}$ Molecular Epidemiology and Biostatistics Laboratory, Gonçalo Moniz Institute, Fiocruz-BA, Salvador, Bahia, Brazil; ${ }^{4}$ Center \\ for Integration of Data and Health Knowledge, Gonçalo Moniz Institute, Fiocruz-BA, Salvador, Bahia, Brazil; ${ }^{5}$ Bahiana School of Medicine and Public \\ Health, Salvador, Bahia, Brazil
}

\begin{abstract}
In Salvador, which is the capital of the Brazilian state of Bahia, it has been estimated that $1.5 \%$ of the general population is infected with hepatitis C virus (HCV); however, the circulation of HCV throughout the state remains unknown. The present retrospective study aimed to determine anti-HCV seroprevalence and describe the geographic distribution of hepatitis C in Bahia. Data from HCV serological tests submitted to the Bahia Central Laboratory of Public Health between 2004 and 2013 were analyzed. Serology for HCV was performed using the AxSYM anti-HCV enzymatic microparticle immunoassay and chemiluminescence immunoassay. A subgroup of samples with detectable HCV-RNA was genotyped using the linear array hepatitis C virus genotyping assay. A total of 247,837 samples were analyzed. The median age of the studied population was 31 years (interquartile range, $25-44$ years), and the female:male ratio was 3.9:1. The global seroprevalence of HCV in Bahia was estimated to be $1.3 \%(3,230 / 247,837)$, corresponding to an infection rate of 21.2/100,000 inhabitants. The seroprevalence of HCV was higher among males and increased with age. The presence of anti-HCV antibodies was detected throughout all mesoregions of Bahia, and the municipality with the highest infection rate was Ipiaú (112.04 cases/100,000 inhabitants). Genotypes 1 and 3 were found to be the most prevalent, followed by genotypes 2, 4, and 5 . Our results provide evidence of the widespread distribution of previous HCV infection throughout the state of Bahia.
\end{abstract}

\section{INTRODUCTION}

The hepatitis $\mathrm{C}$ virus $(\mathrm{HCV})$ is mainly transmitted through the use of contaminated needles, syringes, and instruments used for injection and skin-piercing procedures. ${ }^{1}$ The sexual transmission of HCV is rare. ${ }^{2}$ The majority of cases of acute HCV infection progress to a chronic infection with an asymptomatic course. Approximately two to three decades after the onset of the infection, $10 \%$ to $20 \%$ of infected individuals will develop cirrhosis and $1 \%$ to $5 \%$ will develop hepatocellular carcinoma. ${ }^{3,4}$

It has been estimated that 71 million people worldwide are chronically infected with HCV. A significant number of chronically infected individuals are at risk for cirrhosis or liver cancer. ${ }^{5}$ In Brazil, a national population-based study conducted in the capitals estimated that the overall seroprevalence of anti-HCV antibodies is $1.38 \% .{ }^{6}$ However, the prevalence of this infection varies according to the geographical region and group studied. The groups at most significant risk for infection are intravenous drug users, ${ }^{7}$ individuals undergoing predialysis, ${ }^{8}$ individuals with coagulation disorders, and individuals with chronic renal failure. ${ }^{9}$ Other groups such as health waste handlers, ${ }^{10}$ those undergoing hemodialysis, ${ }^{11}$ incarcerated individuals, ${ }^{12}$ and pregnant women ${ }^{13}$ have higher prevalence rates than individuals in the general population. Despite low frequencies of HCV infection, sex workers, ${ }^{14}$ Amerindians from six tribes in the Eastern Amazon region, ${ }^{15}$ and military personne $\left.\right|^{16}$ all have higher rates than blood donors. ${ }^{17}$

Accordingly, the Notifiable Diseases Information System (SINAN; Brazilian Ministry of Health) has indicated that northeast Brazil has the third highest number of HCV cases in the country. In 2017, the state of Bahia had a detection rate of

*Address correspondence to Maria Fernanda Rios Grassi, Advanced Public Health Laboratory, Gonçalo Moniz Institute, Fiocruz-BA, Rua Waldemar Falcão, 121, Candeal, Salvador, Bahia, Brazil, CEP 40296-710. E-mail: fernanda.grassi@fiocruz.br
anti-HCV or RNA-HCV of 4.5 cases per 100,000 inhabitants. ${ }^{18}$ In the city of Salvador, which is the capital of the state of Bahia, a population-based study reported a $1.5 \%$ prevalence of $\mathrm{HCV}$ infection. ${ }^{19}$ However, the circulation of HCV and genotypes throughout the microregions of Bahia remains unclear. This study aimed to determine the anti-HCV seroprevalence and describe the geographical distribution of $\mathrm{HCV}$ infection in the state of Bahia.

\section{MATERIALS AND METHODS}

Ethical statement. The institutional review board (IRB) for Human Research at the Gonçalo Moniz Institute of the Oswaldo Cruz Foundation (Salvador, Bahia, Brazil) provided ethical approval to conduct this study (CAAE number 22478813.7.0000.0040).

Study area. This study was conducted in the state of Bahia, which is the fourth most populous Brazilian state and the fifth largest area in the country $\left(565,733 \mathrm{~km}^{2}\right)$. In accordance with economic and social similarities among its 417 municipalities, the Brazilian National Institute of Geography and Statistics (IBGE) delineated seven mesoregions that are further grouped into 32 microregions (Figure 1). In 2015, the annual population estimate for Bahia was 15,203,934 inhabitants, resulting in an overall density of 27 inhabitants per square kilometer (http:// www.ibge.gov.br).

Study design. A retrospective ecological study was conducted using data obtained from the Central Laboratory of Public Health of Bahia (LACEN-BA). All serological tests for $\mathrm{HCV}$ were selected among the 32 Bahia microregions from 2004 to 2013. The unique registration number of each sample was considered the key variable. To avoid duplication, the most recent serological results were considered. The target population comprised mainly pregnant women, blood donors, and individuals exhibiting symptoms of infectious disease referred by prenatal physicians, blood banks, or clinicians in the public health system. 


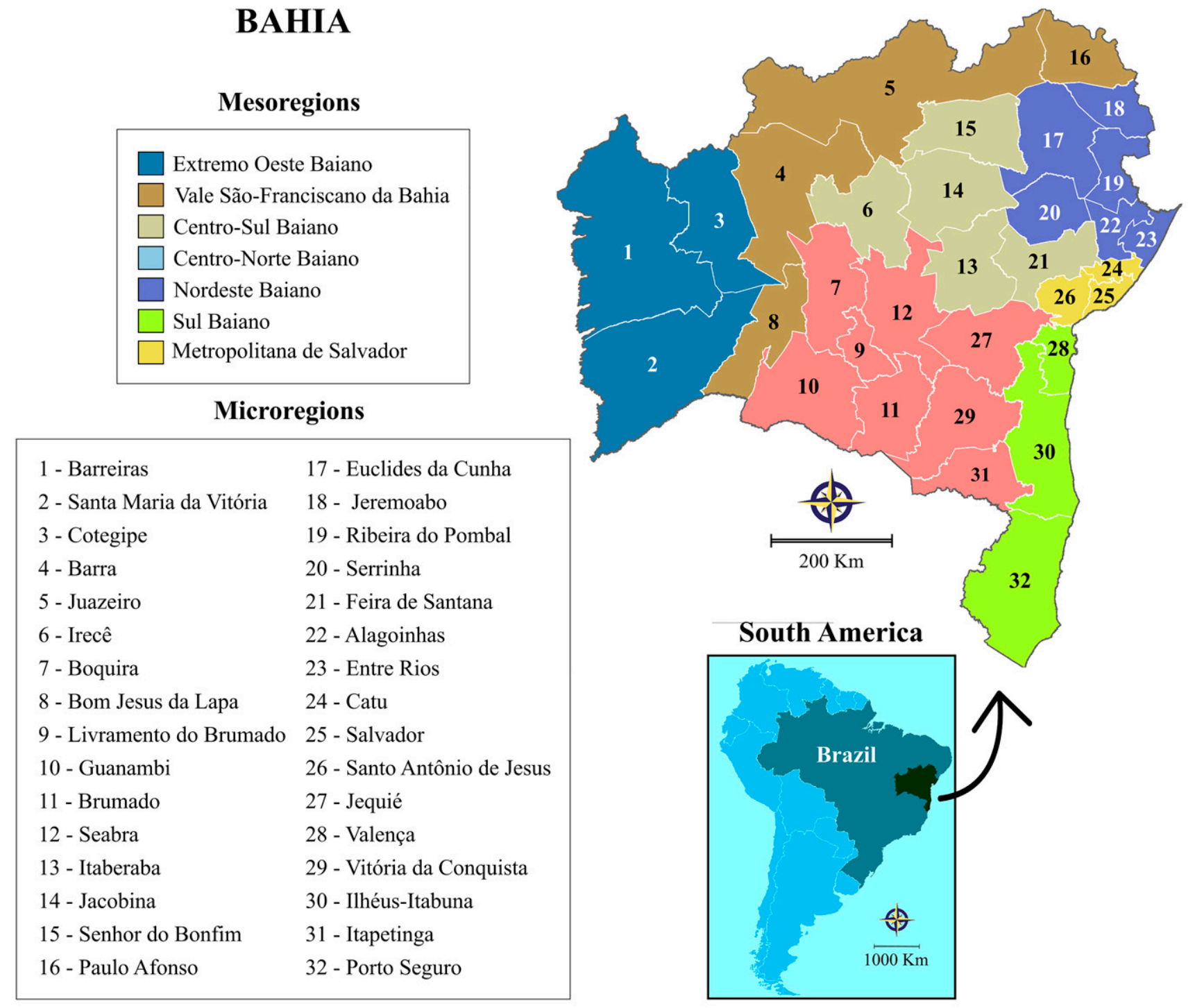

FIGURE 1. Geographic division of the state of Bahia into seven mesoregions and 32 microregions. Digital maps in the public domain were obtained from the Brazilian Institute of Geography and Statistics (IBGE) cartographic database in shapefile format (.shp); these were subsequently reformatted and analyzed using QGIS version 3.10 (Geographic Information System, Open-Source Geospatial Foundation Project; http://qgis.osgeo.org). This figure appears in color at www.ajtmh.org.

Laboratory testing. Serological testing for HCV was performed using a microparticle enzyme immunoassay (MEIA; AxSYM Anti-HCV Abbott Diagnostics Division, Illinois, USA) until 2009; after that time, the chemiluminescent enzyme immunoassay (CLIA) (Architect Anti-HCV; Abbott Diagnostics Division, Wiesbaden, Germany) was implemented for HCV screening. For some MEIA/CLIA-positive samples, physicians ordered confirmation of HCV RNA by quantitative reversetranscription polymerase chain reaction (AMPLICOR $\AA$; Roche Molecular Systems, Branchburg, NJ) if alterations in the clinical status and laboratory parameters were detected. Genotyping analysis, which was requested at the onset of treatment or if resistance was suspected, was performed by analyzing the highly conserved $5^{\prime}$ untranslated region using the Linear Array Hepatitis C Virus Genotyping Test (LiPA; Line Probe Assay, Roche Diagnostics, Indianapolis, IN) according to the manufacturer's guidelines. This assay allows for the determination of six genotypes and subtypes (1a, 1b, 2, 2a, 2b, 3, 3a, 4, 4c, 5, 5a, and 6).

Data analysis. The SMART LABORATORY management system was used to extract data from all serological tests performed during each year of the study period. Validation of the sample database was performed using the $R$ software package, and it was analyzed using STATA v. 13.0. Age is expressed as the median and interquartile range (IQR). Absolute and relative frequencies were calculated for the categorical variables of age (0-15 years, $16-30$ years, $31-50$ years, or 51 years or older), sex (male or female), and serological test (reagent or nonreagent). GraphPad Prism v. 7 (GraphPad Software, San Diego, CA) was used for data analysis; differences were considered statistically significant when $P<0.05$. Rates of infection and coinfection were expressed as the number of individuals infected per 100,000 inhabitants. All HCV cases diagnosed on the municipality level and specifically linked to 
the municipality of residence of each $\mathrm{HCV}$ case were grouped into microregions and mesoregions, which were then used as units for the analyses and comparisons of the different regions to reveal priority areas for interventions. To estimate infection rates, population data were obtained from the Brazilian Institute of Geography and Statistics (IBGE) based on the national census for the period between 2000 and 2010 (https://sidra. ibge.gov.br/pesquisa/censo-demografico/series-temporais/ series-temporais/). The official annual population estimates were used for the remaining years (available at https://sidra. ibge.gov.br/pesquisa/estimapop/tabelas). The 3-year moving averages were calculated between 2004 and 2013. The annual age-adjusted and sex-adjusted incidence rates with corresponding 95\% confidence intervals (Cls) were calculated per 100,000 inhabitants using population census data from 2010 and annual population estimates. Maps were created using the Brazilian annual incidence at the beginning of the studied period as a denominator to illustrate the relative risk of $\mathrm{HCV}$ among the Bahia microregions. Mapping was performed using QGIS software version 3.10 (Geographic Information System, Open-Source Geospatial Foundation Project; freely available at http://qgis.osgeo.org). Digital maps were obtained from the IBGE database in shapefile (.shp) format, which is compatible with the QGIS program.

\section{RESULTS}

A total of 247,837 samples were submitted for HCV serological analysis, with $94.7 \%$ (395/417) coverage of the municipalities throughout the state of Bahia (Figure 2). The median age of the study population was 31 years (IQR, 25-44 years), and the female:male ratio was 3.9:1.

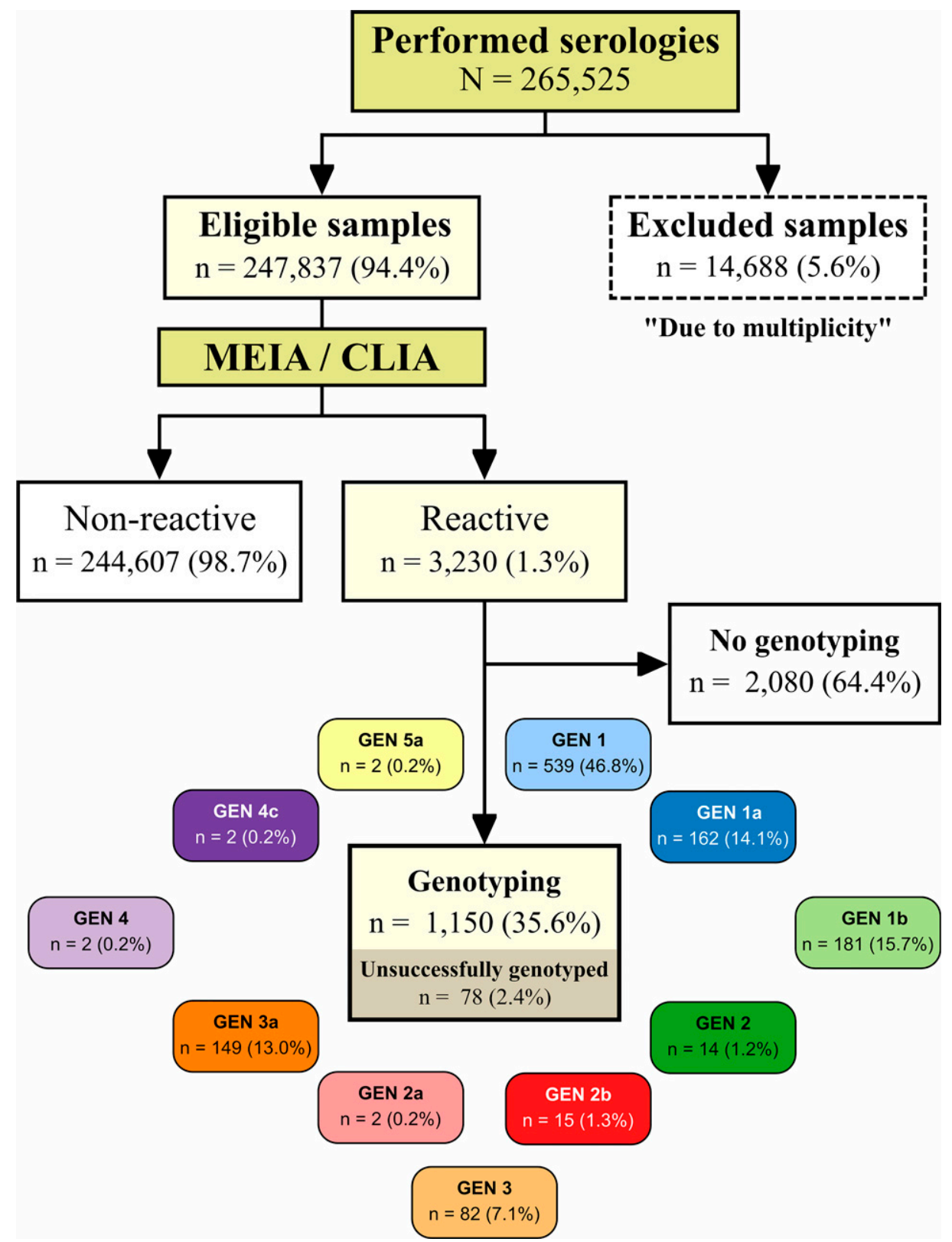

FIGURE 2. Flowchart of the study design. A genotyping analysis was performed for some of the samples (only when requested by the physician at the onset of treatment or if resistance was suspected). This figure appears in color at www.ajtmh.org. 
TABLE 1

Socio-demographic characteristics of individuals evaluated for hepatitis C virus in the state of Bahia, 2004-2013

\begin{tabular}{|c|c|c|c|c|}
\hline \multicolumn{2}{|c|}{ Socio demographic characteristics } & \multirow{2}{*}{$\begin{array}{c}\text { Study population } \\
50,430(20.3 \%) \\
197,407(79.7 \%)\end{array}$} & \multirow{2}{*}{$\begin{array}{c}\text { Individuals with anti-HCV reagent } \\
1,865(3.7 \%) \\
1,365(0.69 \%)\end{array}$} & \multirow{2}{*}{$\frac{P \text { value }}{<0.0001}$} \\
\hline Sex, N (\%) & $\begin{array}{l}\text { Male } \\
\text { Female }\end{array}$ & & & \\
\hline Age, years & Mean (IQR) & $41(26-43)$ & $55(42-61)$ & $<0.0001$ \\
\hline Origin, N (\%) & $\begin{array}{l}\text { Salvador (capital) } \\
\text { Others municipalities }\end{array}$ & $\begin{array}{r}53,974(21.8 \%) \\
193,863(78.2 \%)\end{array}$ & $\begin{array}{l}1,603(49.6 \%) \\
1,627(50.4 \%)\end{array}$ & $<0.0001$ \\
\hline
\end{tabular}

$\mathrm{HCV}=$ hepatitis $\mathrm{C}$ virus; IQR $=$ interquartile range.

The overall prevalence of anti-HCV in the sample was $1.3 \%$ $(3,230 / 247,837 ; 95 \% \mathrm{Cl}: 1.26-1.35)$ (Figure 1). The HCV seroprevalence rates were $3.7 \%(1,865 / 50,430 ; 95 \% \mathrm{Cl}, 3.5-3.9)$ among males and $0.69 \%(1,365 / 197,407 ; 95 \% \mathrm{Cl}$, $0.66-0.73)$ among females $(P<0.0001)$ (Table 1$)$. The median age of the 197,407 females was 30.9 years (IQR, 24.6-39.9 years); however, it was 42.3 years (IQR, 30.0-58.0 years) for 50,430 males. For both sexes, the prevalence was found to increase significantly for individuals older than 31 years (males: $P<0.0001$; females: $P<0.0001$ ). Thirty individuals 15 years or younger presented positive serology for HCV, including three individuals younger than 4 years (Figure 3 ).

Of the municipalities that sent samples for evaluation, antiHCV positivity was detected in $55.2 \%$ (218/395). The cumulative mean rate of positive HCV cases was 25.0 per 100,000 inhabitants in Bahia. Information regarding the city of origin was lacking for $0.7 \%$ of the anti-HCV-positive samples. Regarding the spatiotemporal distribution of HCV positivity in all microregions of Bahia at eight distinct time points (Figure 4), no difference was found in the number of positive cases, as evidenced by the first period of study (2005) during which 2.81 HCV cases per 100,000 inhabitants was found compared with 2.62 cases per 100,000 inhabitants during the final period (2012). However, an increase in the number of positive cases was observed, especially in the microregions of Senhor do Bonfim (0.17 cases per 100,000 inhabitants in 2005 versus 2.77 cases per 100,000 inhabitants in 2012) and Serrinha ( 0.45 cases per 100,000 inhabitants in 2005 versus 2.97 cases per 100,000 inhabitants in 2012).

In contrast, a decrease in the number of cases was observed in the microregions of Juazeiro (8.22 cases per 100,000 inhabitants in 2005 versus 0.29 cases per 100,000 inhabitants in 2012), Salvador (7.77 cases per 100,000 inhabitants in 2005 versus 4.79 cases per 100,000 inhabitants in 2012), Catu

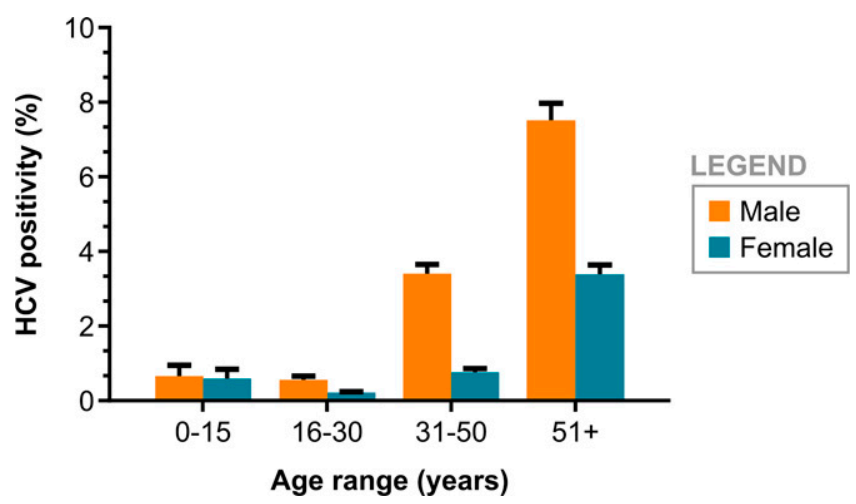

FigurE 3. Anti-hepatitis C virus (anti-HCV) positivity among 45,199 males and 185,703 females according to age group in Bahia, Brazil, from 2004 to 2013. This figure appears in color at www.ajtmh.org.
( 2.78 cases per 100,000 inhabitants in 2005 versus 1.36 cases per 100,000 inhabitants in 2012), and Barreiras (2.45 cases per 100,000 inhabitants in 2005 versus 0.89 cases per 100,000 inhabitants in 2012).

Considering the grouping of anti-HCV-positive samples into microregions (Figure 5), seven areas demonstrated rates more than $20 \mathrm{HCV}$-positive cases per 100,000 inhabitants: Metropolitan Region of Salvador (53.47 cases per 100,000 inhabitants), Senhor do Bonfim (29.95 cases per 100,000 inhabitants), Juazeiro (28.22 cases per 100,000 inhabitants), Paulo Afonso (27.82 cases per 100,000 inhabitants), Porto Seguro (25.83 cases per 100,000 inhabitants), Feira de Santana (23.01 cases per 100,000 inhabitants), and Ilhéus-Itabuna (21.26 cases per 100,000 inhabitants). Rates of anti-HCV seroprevalence ranging from 15 to 20 cases per 100,000 inhabitants were also seen in five other microregions. In the remaining microregions, a homogenous distribution of anti-HCV positivity was observed. No information was retrieved from one microregion (Jeremoabo), however.

The HCV genotype was determined for 1,150 (35.6\%) of the 3,230 cases with anti-HCV antibodies. Seventy-eight samples were not successfully genotyped. Genotypes $1(46.98 \%), 1 a(14.1 \%)$, and $1 b(15.7 \%)$ were the most frequently obtained, followed by genotypes $3 a(13.0 \%)$, $3(7.1 \%), 2(1.2 \%), 2 a(0.2 \%)$, and $2 b(1.3 \%)$. Genotypes $4(0.2 \%), 4 \mathrm{c}(0.2 \%)$, and $5 \mathrm{a}(0.2 \%)$ were less frequently identified. Some isolates could not be subtyped. Genotypes 1, 1a, $1 b, 2,2 a, 2 b, 3$, and $3 a$ were present among the seven mesoregions of the state, but genotype 4 was detected in mesoregions Metropolitan Region of Salvador and Sul Baiano. Genotype 5 was detected in the mesoregions of Centro Sul and Extremo Oeste (Figure 6).

\section{DISCUSSION}

The data obtained during the present study demonstrate that the overall seroprevalence of HCV antibodies was $1.3 \%$ $(3,230 / 247,837)$. The HCV infection rate found during this study is consistent with the prevalence $(1.5 \%)$ of a population-based study in Salvador (the state capital) ${ }^{19}$ and that found during the national survey of viral hepatitis (1.38\%) performed in the capitals of Brazil. ${ }^{6}$ However, this prevalence was higher than estimated for anti-HCV $(0.94 \%)$ in the capitals of the northeast region. ${ }^{6}$ Prevalence studies evaluating the general population are rare. In Brazil, the prevalence of HCV ranges from $2.4 \%$ to $47 \%$ for vulnerable groups such as drug users (28.3\%), individuals with renal failure (12.6\%), individuals with coagulation disorders (47\%), waste handlers (3.3\%), and incarcerated individuals $(2.4 \%) .^{8-10,12,20}$ However, the prevalence of HCV is lower for sex workers and transgender women, and it remained 

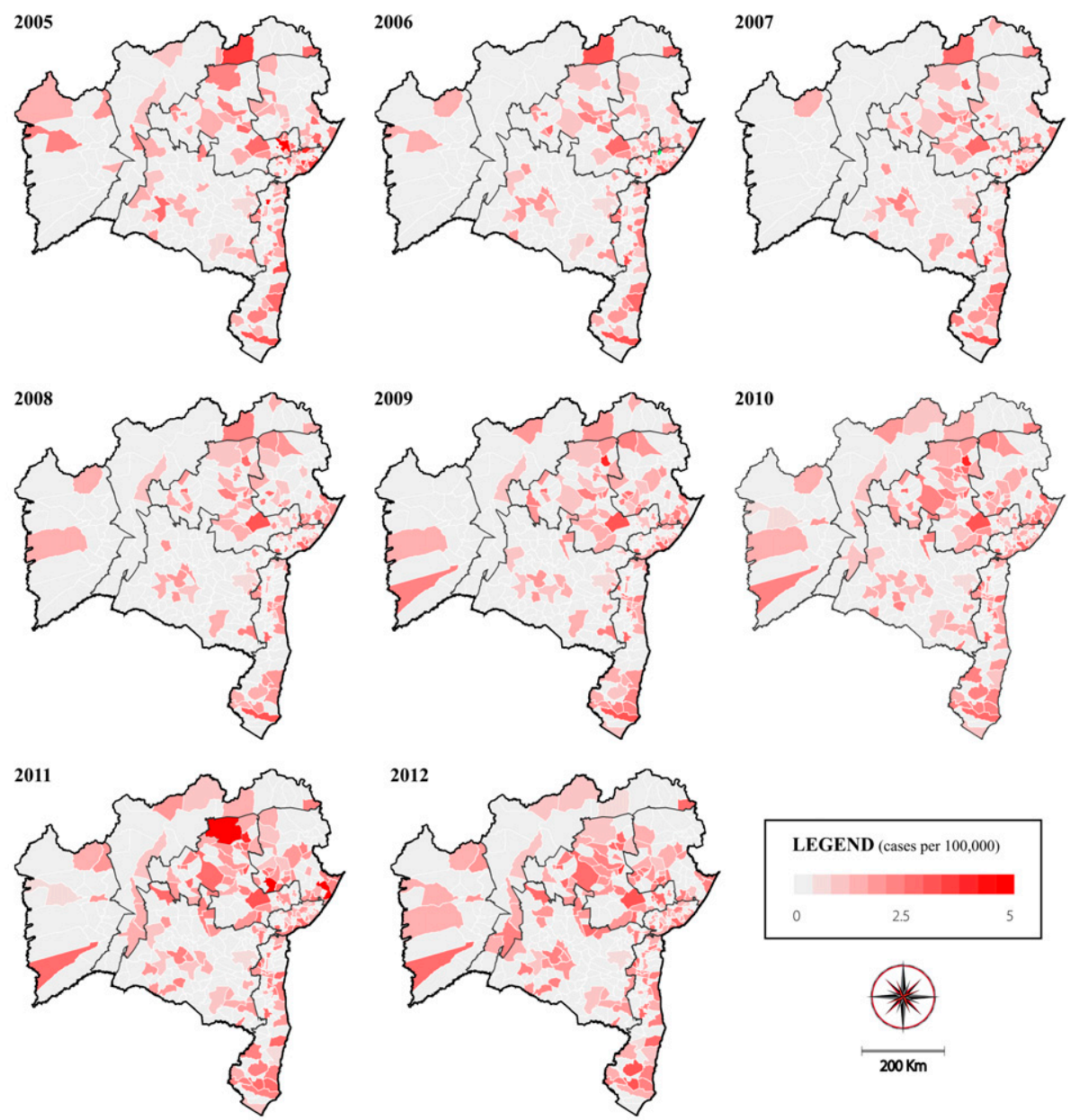

FIGURE 4. Spatiotemporal distribution of anti-hepatitis C virus (anti-HCV) positivity in the state of Bahia from 2004 to 2013, calculated using 3-year moving averages and considering the microregions or the state as units of analysis. This figure appears in color at www.ajtmh.org.

less than $0.1 \%$ for blood donors and manual sugarcane cutters. $^{14,17,21,22}$

There is no information regarding the geographical distribution of the anti-HCV seroprevalence in Bahia, which is the state with the largest population in the northeast and the fourth largest in Brazil. The present study demonstrates that individuals seropositive for anti-HCV antibodies were distributed throughout 31 of the 32 microregions of the state, thus corresponding to an overall rate of 21.2 cases per 100,000 individuals. Of note, the number of anti-HCV-positive cases in the state of Bahia remained similar throughout the study period ( $<3$ cases per 100,000 inhabitants). However, variations between microregions were observed. The microregions with the highest rates of anti-HCV antibodies were IlhéusItabuna, Feira de Santana, Porto Seguro, Salvador, Jacobina, and Senhor do Bonfim, which are characterized as the great economic poles of the state because of their commercialism and tourism.

Notably, the city of Ipiaú, located in the Ilhéus-Itabuna microregion, had the highest anti-HCV rate per 100,000 inhabitants (112.04). We speculate that this high rate is associated with intravenous drug use as well as greater access to the diagnosis of HCV infection. Currently, the state of Bahia has 32 testing and counseling centers that provide screening for sexually transmitted infections and HCV. One of these testing and counseling centers is located in Ipiaú municipality. However, data regarding blood transfusion history and intravenous drug use were not available; therefore, it was not possible to estimate the probable route of infection. The incidence of transfusion-associated HCV was relatively high before the 1990s. Currently, injection drug use is considered the main route of HCV transmission in Brazil and the United States. ${ }^{6,23}$

Regarding the profile of HCV circulating genotypes in Bahia, the present study detected the presence of genotypes 1, 2, 3, 4 , and 5 . Genotype 1 and its subtypes $(76.7 \%)$ were the most prevalent, followed by genotypes $3 a(13.0 \%)$ and 3 (7.1\%). It has been reported that HCV genotypes 1 and 3 are the most prevalent worldwide, accounting for approximately $46.2 \%$ and $30.1 \%$ of infections, respectively. ${ }^{24}$ Genotype 4 has been found most often in north Africa and the Middle East, whereas genotype 5 is more prevalent in South Africa. ${ }^{25,26}$ In relation to Brazil, genotype 1 is widely distributed in the different geographic regions of the country, genotype 2 is more frequent in the midwestern region, and 3 is more frequent in the southern region. ${ }^{27}$ Interestingly, in the present study, four cases of genotype $4 \mathrm{HCV}$ infection were identified in the cities of Ipiaú, Teixeira de Freitas, and Salvador, and two genotype 5 cases were found in Vitória da Conquista and São Felix do 


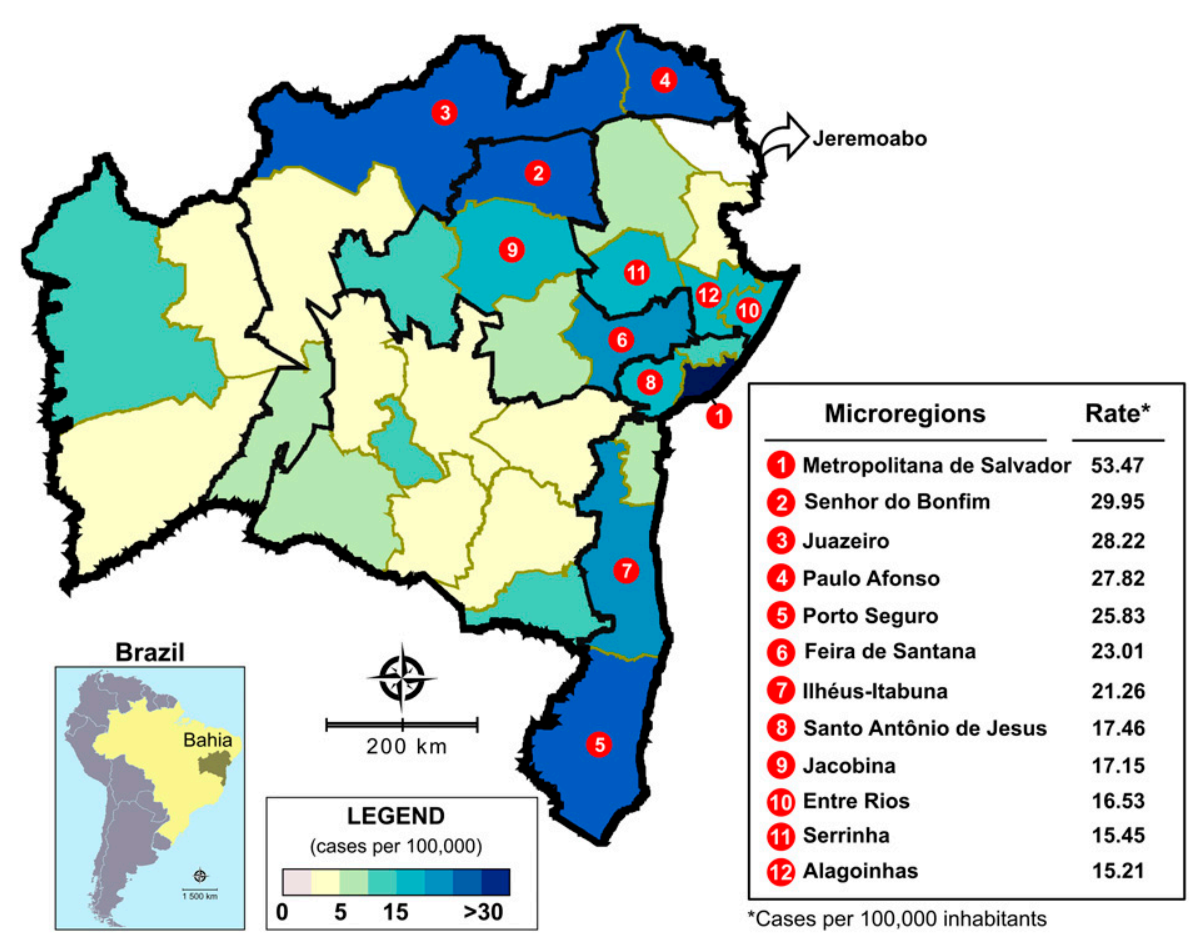

FIGURE 5. Spatial distribution of overall anti-hepatitis C virus (anti-HCV) positivity in the state of Bahia from 2004 to 2013 , considering microregions as the unit of analysis. The 12 microregions with the highest rates of anti-HCV positivity per 100,000 inhabitants are highlighted. No information was retrieved from the Jeremoabo microregion (arrow). This figure appears in color at www.ajtmh.org.

Coribe. The presence of genotype 4 was first recorded in Brazil in the city of São Paulo in a patient who underwent kidney transplantation ${ }^{28}$; thereafter, it was found in an intravenous drug user in Salvador. ${ }^{29}$ HCV genotype 5 infections have been reported for only three individuals in the city of São Paulo in 2001. ${ }^{30}$

Regarding the demographic profile of individuals seropositive for anti-HCV antibodies in the present study, the average age was 55 years and most were males. However, the population evaluated during this study mainly comprised females. Interestingly, when the overall prevalence of anti-HCV antibodies was extrapolated to consider the entire population of the state of Bahia (i.e., all males and females), a similar prevalence $(0.021 \% ; 3,230$ cases $/ 15.2$ million inhabitants) was found $(0.03 \%$ versus $0.02 \%$, respectively). Similar demographic profiles have been described in reports of studies conducted in other regions of Brazil and Bahia. . $^{619,31,32}$ In fact, it was expected that $\mathrm{HCV}$ infection would be more frequent in individuals 50 years or older because the laboratory diagnosis of HCV was adopted in 1989, and testing of blood donors became mandatory in Brazil only in 1993. ${ }^{33}$ Before this period, the sharing of syringes and the use of glass syringes were common practices and factors that contributed to $\mathrm{HCV}$ dissemination. ${ }^{1}$

In the present study, 3,230 cases of seropositive anti-HCV antibodies were diagnosed in 218 municipalities, thus corresponding to $52.2 \%$ of the municipalities of the state. From 2004 to 2013, the same period of this study, the state of Bahia registered 2,739 cases of $\mathrm{HCV}$ from 140 municipalities of the state in the Notifiable Disease Information System (SINAN). ${ }^{18}$ This could indicate the underreporting of HCV infection despite the notification of $\mathrm{HCV}$ infection being compulsory in Brazil since 1996. Considering the population of 15.2 million individuals in Bahia in 2015, 197,600 cases of HCV infection would be expected; of these, 138,320 would progress to chronic hepatitis ( $70 \%$ of cases), 27,664 (20\%) would progress to cirrhosis, and 1,106 (4\%) would progress to hepatocellular carcinoma.

This study was limited by nonrandomized sampling procedures and the predominant representation of females. Because the Brazilian Ministry of Health recommends screening pregnant women for sexually transmitted diseases, such as HIV and human T-lymphotropic virus, as well as hepatitis $B$ virus and $\mathrm{HCV}$, the Central Laboratory of Public Health of Bahia receives many samples from pregnant women, thus undoubtedly lending bias to the present results. Another limitation was that the presence of antibodies against HCV does not necessarily reflect active infection. Furthermore, of all samples with anti-HCV positivity, approximately $35 \%$ were submitted for PCR testing and approximately $33 \%$ were successfully genotyped. Our study was additionally limited by the lack of information regarding risk factors for HCV infection. However, regarding the representativeness of the municipalities, $94.7 \%$ of the state municipalities were evaluated throughout the study, thereby allowing us to evaluate the spatial distribution of HCV infection.

In conclusion, the results obtained during this study demonstrate that HCV was previously widespread throughout the state of Bahia. The predominance of males among anti-HCV seropositive subjects may reflect intravenous drug use in urban and rural areas. Studies evaluating the risk factors associated with the presence of HCV in these areas should be 
STATE OF BAHIA

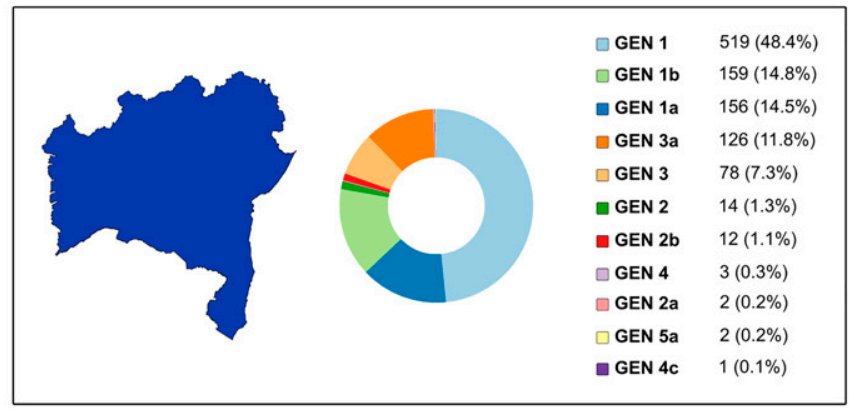

VALE DO SÃO FRANCISCO

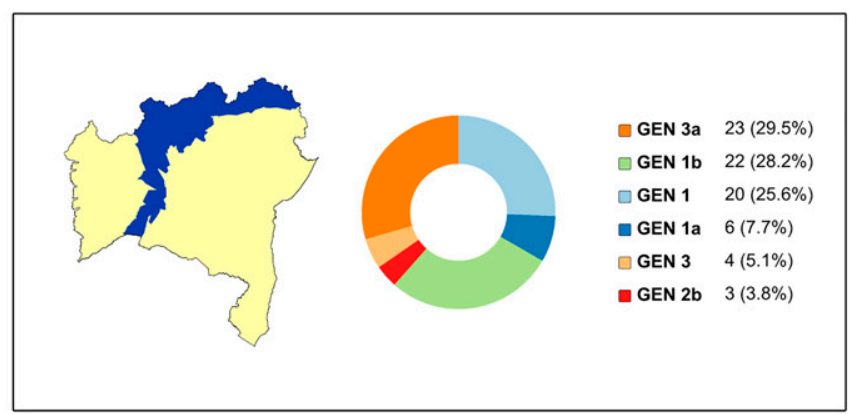

CENTRO SUL BAIANO

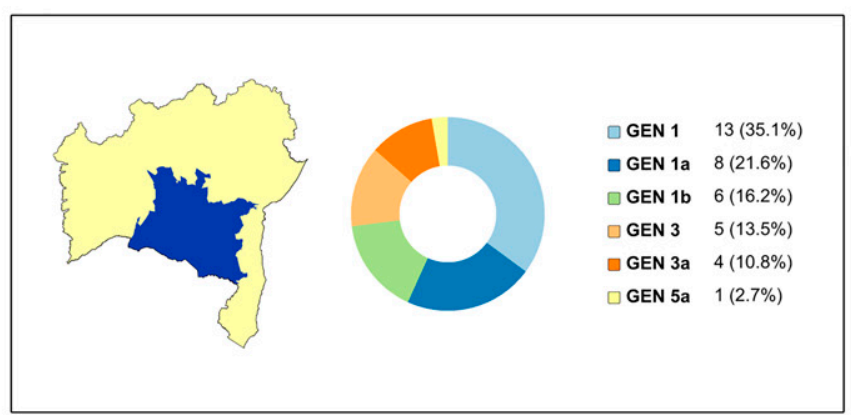

EXTREMO OESTE BAIANO

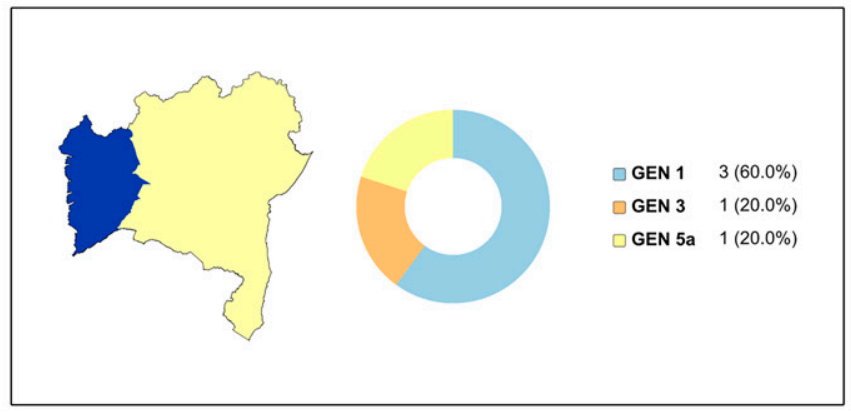

CENTRO NORTE BAIANO

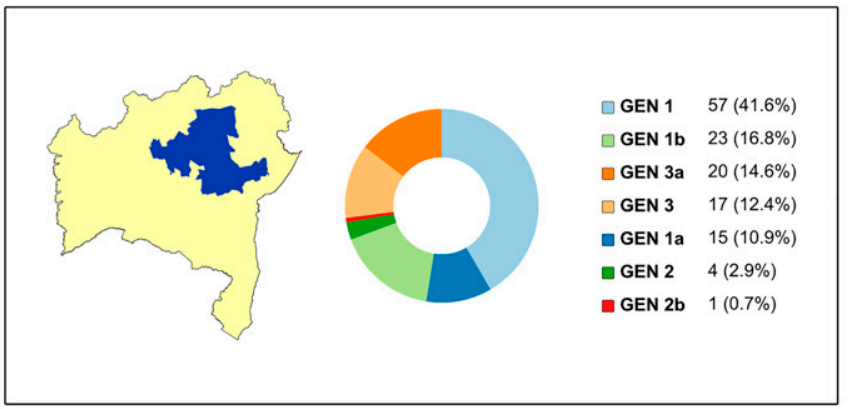

NORDESTE BAIANO

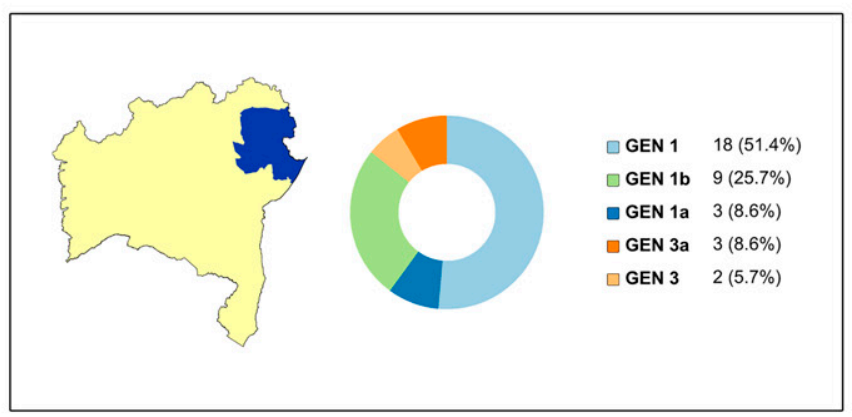

SUL BAIANO

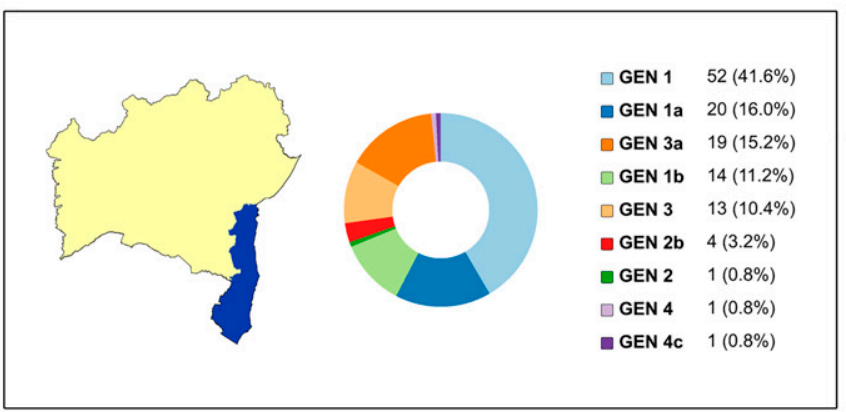

METROPOLITANA DE SALVADOR

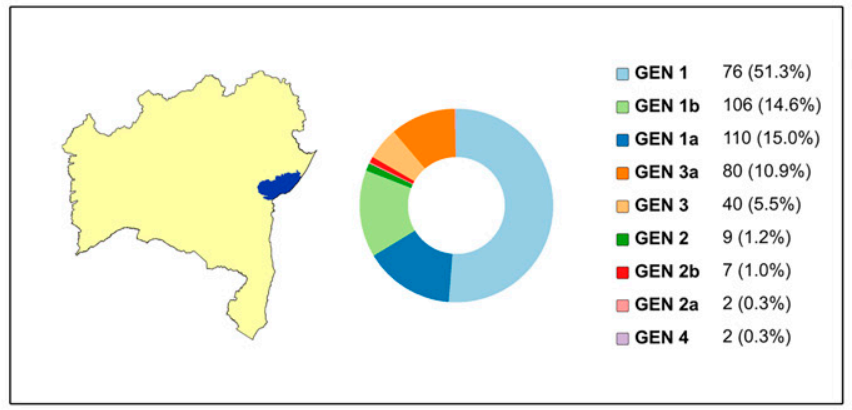

FIGURE 6. Distribution of hepatitis C virus (HCV) genotypes from 1,150 individuals infected in the mesoregions of the state of Bahia, Brazil, from 2004 to 2013. This figure appears in color at www.ajtmh.org.

conducted to support more effective public prevention policies and identify patients who need treatment.

Received December 21, 2020. Accepted for publication June 6, 2021.

Published online August 23, 2021.

Financial support: This work was supported by the Coordination of Superior Level Staff Improvement-Brazil (CAPES) (finance code 001) and National Foundation for the Development of Private Higher Education (FUNADESP) grants 9600140 and 9600141.
Disclaimer: Maria Fernanda R. Grassi, Bernardo Galvão-Castro, and Fred Luciano Neves Santos are research fellows of CNPq (process no. 304811/2017-3, 311054/2014-5, and 309263/2020-4, respectively). The funding agencies were not involved in any aspect of the study including design, analysis, or interpretation of results.

Authors' addresses: Felicidade Mota Pereira, Gonçalo Moniz Public Health Central Laboratory (LACEN), Salvador, Bahia, Brazil E-mail: felizmp@yahoo.com.br. Fred Luciano Neves Santos, Advanced Public Health Laboratory, Gonçalo Moniz Institute, Fiocruz-BA, Salvador, Bahia, Brazil, E-mail: fred.santos@fiocruz.br. Maria da Conceição 
Chagas de Almeida, Molecular Epidemiology and Biostatistics Laboratory, Gonçalo Moniz Institute, Fiocruz-BA, Salvador, Bahia, Brazil, E-mail: conceicao.almeida@fiocruz.br. Roberto Perez Carreiro, Center for Integration of Data and Health Knowledge, CIDACS, Gonçalo Moniz Institute, Fiocruz-BA, Salvador, Bahia, Brazil, E-mail: roberto.carreiro@gmail.com. Luciano Kalabric Silva, Bernardo Galvão-Castro, and Maria Fernanda Rios Grassi, Bahiana School of Medicine and Public Health, Salvador, Bahia, Brazil, E-mails: Iuciano. kalabric@fiocruz.br, bgalvao@bahiana.edu, and fernanda.grassi@ fiocruz.br.

This is an open-access article distributed under the terms of the Creative Commons Attribution (CC-BY) License, which permits unrestricted use, distribution, and reproduction in any medium, provided the original author and source are credited.

\section{REFERENCES}

1. Alter MJ, 2002. Prevention of spread of hepatitis C. Hepatology 36 (Suppl 1): S93-S98.

2. Alter MJ, Mast EE, Moyer LA, Margolis HS, 1998. Hepatitis C. Infect Dis Clin North Am 12: 13-26.

3. Alter HJ, 1995. To C or not to C: these are the questions. Blood 85 : 1681-1695.

4. Lavanchy D, 2011. Evolving epidemiology of hepatitis $C$ virus. Clin Microbiol Infect 17: 107-115.

5. World Health Organization (WHO), 2020. Hepatitis C. Geneva, Switzerland: WHO. Available at: https://www.who.int/newsroom/fact-sheets/detail/hepatitis-c. Accessed July 27, 2020.

6. Pereira LMMB et al., 2013. Prevalence and risk factors of hepatitis $C$ virus infection in Brazil, 2005 through 2009: a cross-sectional study. BMC Infect Dis 13: 60.

7. Silva FQ, Santos FJA, Andrade AP, Pacheco SDB, Fischer B, Pinho JRR, Lemos JAR, Oliveira-Filho AB, 2018. Hepatitis C virus infection among illicit drug users in an archipelago of the Amazon. Arch Virol 163: 617-622.

8. Sette LHBC, Lopes EP de A, dos Anjos NCG, Valente LM, de Oliveira SAV, Lucena-Silva N, 2019. High prevalence of occult hepatitis C infection in predialysis patients. World $\mathrm{J}$ Hepatol 11: 109-118.

9. Ribeiro Barbosa J, Sousa Bezerra C, Carvalho-Costa F, Pimentel de Azevedo C, Lopes Flores G, Baima Colares J, Malta Lima D, Lampe E, Melo Villar L, 2017. Cross-sectional study to determine the prevalence of hepatitis $B$ and $C$ virus infection in high risk groups in the northeast region of Brazil. Int $J$ Environ Res Public Health 14: 793.

10. Mol MP, Gonçalves JP, Silva EA, Scarponi CF, Greco DB, Cairncross S, Heller L, 2016. Seroprevalence of hepatitis B and C among domestic and healthcare waste handlers in Belo Horizonte, Brazil. Waste Manag Res 34: 875-883.

11. Cordeiro VM et al., 2018. Decline in hepatitis B and C prevalence among hemodialysis patients in Tocantins, northern Brazil. Rev Inst Med Trop Sao Paulo 60.

12. Puga MAM et al., 2017. Prevalence and incidence of HCV infection among prisoners in Central Brazil. Khudyakov YE, ed. PLoS One 12: e0169195.

13. de Oliveira Barros MM, Oliveira de Moura Ronchinde KR, Salerno Soares RL, 2018. Hepatitis B and C in pregnant women attended by a prenatal program in an universitary hospital in Rio de Janeiro, Brazil: retrospective study of seroprevalence screening. Arq Gastroenterol 55: 267-273.

14. Ferreira-Júnior O da C, Guimarães MDC, Damacena GN, de Almeida W da S, de Souza-Júnior PRB, Szwarcwald CL, 2018. Prevalence estimates of HIV, syphilis, hepatitis B and C among female sex workers (FSW) in Brazil, 2016. Medicine (Baltimore) 97: S3-S8.
15. Villar LM, Milagres FAP, Lampe E, Cruz HM, Scalioni L de P, Magalhães M de AFM, Romão AR, Gracie R, de Paula VS, 2018. Determination of hepatitis $B, C$ and $D$ prevalence among urban and Amerindian populations from the eastern Brazilian Amazon: a cross sectional study. BMC Infect Dis 18: 411.

16. Villar LM, 2015. Prevalence of hepatitis $B$ and $C$ virus infections among military personnel. Braz J Infect Dis 19: 285-290.

17. Levi JE, Lira SM, Bub CB, Polite MB, Terzian CC, Kutner JM, 2017. Contrasting HCV and HIV seroepidemiology in 11 years of blood donors screening in Brazil. Transfus Med 27: 286-291.

18. Ministério da Saúde Brasil, 2020. Secretaria de Vigilância em Saúde. Programa Nacional de DST e Aids. Boletim Epidemiológico - Hepatites Virais. Available at: http://www.aids. gov.br/pt-br/pub/2020/boletim-epidemiologico-hepatitesvirais-2020.

19. Zarife MAS, Silva LK, Silva MBS, Lopes GB, Barreto ML, Teixeira M da G, Dourado I, Reis MG, 2006. Prevalence of hepatitis C virus infection in north-eastern Brazil: a population-based study. Trans R Soc Trop Med Hyg 100: 663-668.

20. Silva IC et al., 2018. Moderada endemicidade da infecção pelo vírus linfotrópico-T humano na região metropolitana de Belém, Pará, Brasil. Rev Bras Epidemiol 21. doi: 10.1590/1980549720180018.

21. Bastos Fl et al., 2018. HIV, HCV, HBV, and syphilis among transgender women from Brazil. Medicine (Baltimore) 97: S16-S24.

22. de Castro Rocha DFN et al., 2018. Epidemiology of HIV, syphilis, and hepatitis $\mathrm{B}$ and $\mathrm{C}$ among manual cane cutters in lowincome regions of Brazil. BMC Infect Dis 18: 546.

23. Alter MJ, Kruszon-Moran D, Nainan OV, McQuillan GM, Gao F, Moyer LA, Kaslow RA, Margolis HS, 1999. The prevalence of hepatitis C virus infection in the United States, 1988 through 1994. N Engl J Med 341: 556-562.

24. Messina JP, Humphreys I, Flaxman A, Brown A, Cooke GS, Pybus OG, Barnes E, 2015. Global distribution and prevalence of hepatitis $C$ virus genotypes. Hepatology 61: 77-87.

25. Gower E, Estes C, Blach S, Razavi-Shearer K, Razavi H, 2014. Global epidemiology and genotype distribution of the hepatitis C virus infection. J Hepatol 61: S45-S57.

26. Petruzziello A, Marigliano S, Loquercio G, Cozzolino A, Cacciapuoti C, 2016. Global epidemiology of hepatitis C virus infection: an up-date of the distribution and circulation of hepatitis C virus genotypes. World J Gastroenterol 22: 7824.

27. Campiotto $S$ et al., 2005. Geographic distribution of hepatitis $C$ virus genotypes in Brazil. Braz J Med Biol Res 38: 41-49.

28. Bassit L, Ribeiro-Dos-Santos G, Da Silva LC, Takei K, Villaça P, David-Neto E, Chamone D, Sáez-Alquézar A, 1999. Genotype distribution of hepatitis $C$ virus in São Paulo, Brazil: rare subtype found. Hepatology 29: 994-995.

29. Zarife MASA, de Oliveira ECP, Romeu JMSL, dos Reis MG, 2006. Detecção do genótipo 4 do vírus da hepatite $C$ em Salvador, BA. Rev Soc Bras Med Trop 39: 567-569.

30. Levi JE et al., 2002. Three cases of infection with hepatitis $C$ virus genotype 5 among Brazilian hepatitis patients. J Clin Microbiol 40: 2645-2647.

31. Foccacia $R$ et al., 1998. Estimated prevalence of viral hepatitis in the general population of the municipality of São Paulo, measured by a serologic survey of a stratified, randomized and residence-based population. Braz J Infect Dis 2: 269-284

32. Nascimento MC, Mayaud P, Sabino EC, Torres KL, Franceschi S, 2008. Prevalence of hepatitis B and C serological markers among first-time blood donors in Brazil: a multi-center serosurvey. J Med Virol 80: 53-57.

33. Ministério da Saúde, 2016. Portaria no. 158, de 4 de Fevereiro de. Available at: https://bvsms.saude.gov.br/bvs/saudelegis/gm/ 2016/prt0158_04_02_2016.html. 